\title{
RECOMBINANT ADENO-ASSOCIATED VIRUSES AS A GENE DELIVERY VEHICLE FOR THE USE IN MOLECULAR MEDICINE
}

Usman NYu1 ${ }^{1}$, Rebrikov DV ${ }^{1,2}$

${ }^{1}$ Kulakov National Medical Research Center for Obstetrics, Gynecology and Perinatology, Moscow, Russia

${ }^{2}$ Center for Precision Genome Editing and Genetic Technologies for Biomedicine, Pirogov Russian National Research Medical University, Moscow, Russia

Viral mechanisms for the delivery of genetic material are widely used in molecular medicine. Recombinant adeno-associated viruses ( $\mathrm{rAAV}$ ) represent a promising tool for in vivo gene delivery. The review considers nosological spectrum, molecular mechanisms, the choice of drug administration route depending on target structures, the choice of serotype, and the methods of active ingredient manufacturing for rAAV-mediated gene therapy.

Keywords: adeno-associated viruses, AAV, rAAV, gene therapy

Author contribution: Usman NYu — preparation of the manuscript; Rebrikov DV — editing of the manuscript.

Correspondence should be addressed: Natalia Usman

Oparina, 4, Moscow, 117997, Russia; natalia.usman@yandex.ru

Received: 19.10.2021 Accepted: 29.10.2021 Published online: 31.10.2021

DOI: $10.24075 /$ brsmu.2021.051

\section{РЕКОМБИНАНТНЫЕ АДЕНОАССОЦИИРОВАННЫЕ ВИРУСЫ КАК СРЕДСТВО ДОСТАВКИ ГЕНОВ ДЛЯ ИСПОЛЬЗОВАНИЯ В МОЛЕКУЛЯРНОЙ МЕДИЦИНЕ}

\author{
Н. Ю. Усман ${ }^{1 凶}$, Д. В. Ребриков ${ }^{1,2}$ \\ 1 Национальный медицинский исследовательский центр акушерства,гинекологии и перинатологии имени В. И. Кулакова, Москва, Россия \\ ${ }^{2}$ Центр высокоточного редактирования и генетических технологий для биомедицины, Российский национальный исследовательский медицинский \\ университет имени Н. И. Пирогова, Москва, Россия
}

\begin{abstract}
Вирусные механизмы доставки генетического материала широко используются в молекулярной медицине. Рекомбинантные аденоассоциированные вирусы (rAAV) представляют собой перспективный инструмент для доставки генов in vivo. В обзоре представлены нозологический спектр, молекулярные механизмы, выбор способа введения препарата в зависимости от структур-мишеней, выбор серотипа, а также методы производства активных ингредиентов для rAAV-опосредованной генной терапии.
\end{abstract}

Ключевые слова: аденоассоциированные вирусы, AAV, rAAV, генотерапия

Вклад авторов: Н. Ю. Усман - подготовка рукописи; Д. В. Ребриков - редактирование рукописи.

$\triangle$ Для корреспонденции: Наталья Юрьевна Усман

Опарина, д. 4, г. Москва, 117997, Россия; natalia.usman@yandex.ru

Статья получена: 19.10.2021 Статья принята к печати: 29.10.2021 Опубликована онлайн: 31.10.2021

DOI: $10.24075 /$ vrgmu.2021.051

\section{Biological basis for the recombinant adeno-associated virus-mediated gene delivery}

Adeno-associated viruses (AAV, Dependoparvovirus, Parvoviridae) were discovered as impurities in laboratory preparations of adenoviruses. The interest in AAV, which had long been purely scientific, moved into a practical plane in connection with the development of gene therapy.

AAV infectious particles are icosahedral. The capsid is assembled of three types of protein subunits, variants of which determine the specificity of viral particles in relation to the recipient's immune system (serotype). The genome is flanked with inverted terminal repeats (ITR) of T-shaped secondary structure, which prime the complementary DNA synthesis in the infected cell nucleus. In addition, ITR serve as recombinogenic sequences for the formation of transcribed concatemeric molecules of viral DNA; they also provide a replication origin and a packaging signal. The AAV genome contains two coding genes, rep and cap, with multiple reading frames - rep for the factors of replication and particle assembly and cap for capsid proteins. It is important to emphasize that AAV life cycle can only be maintained upon coinfection of the host cell with other viruses.

Viral mechanisms for the delivery of genetic material are widely used in molecular medicine. For their implementation, a prototype viral genome sequences are distributed over different carrier (vector) DNA molecules. Structuring and regulatory elements of the virus are cloned into one vector, with a therapeutic module (cargo) subsequently incorporated to obtain a composite (recombinant) unit intended for the packaging and delivery. Coding sequences of own genes of the virus are cloned into another vector. The use of vectorized DNA fragments that complement one another functionally while being physically disconnected is called trans-complementation. This is a 'kill two birds with one stone' solution, as (1) the extraction of viral coding sequences makes room for the cargo; (2) the delivery is safe for the target cell, as certain genes essential for self-maintenance of the virus have been removed from the recombinant version of its genome intended for the delivery. Production of viral particles proceeds in a living eukaryotic cell. Having received both vectors, this cell begins to produce infectious particles containing the recombinant viral DNA.

Recombinant AAVs (rAAVs) represent a promising platform for in vivo gene delivery. Compared with alternative systems, rAAVs have a number of advantages:

1) the absence of human pathogens among known AAV strains offsets the risks associated with sporadic transgression of the virus to the wild type;

2) rAAV sequences do not integrate in the target cell genomes, which is a principal safety factor for in vivo applications (in humans, wild-type AAVs are capable of integration into 
genomic locus AAVS1, which results in latency. The integration is based on structural similarity between ITR and AAVS1 and requires participation of viral proteins Rep. Recombinant AAVs are devoid of rep coding sequences and do not integrate);

3) small infectious particles of AAV (20-26 nm) have higher penetrating capacity compared to retro- and lentiviruses (100-200 nm), certain AAV serotypes can cross the bloodbrain barrier.

At the same time, rAAV gene therapy platforms have a number of drawbacks, first of all, the expensive complex production and the need of using genetic elements of other viruses (adeno-, herpes simplex, or baculo-) as a potential source of biological contamination. Other disadvantages of rAAV platforms include the risk of excessive immune response to the therapy and tight restrictions on the size of the cargo [1-3].

\section{Indications for the rAAV-mediated gene delivery}

Despite its historical focus on monogenic autosomal-recessive disorders, the scope of indications for the use of gene therapy with rAAV delivery is much wider. The possibility of using rAAV is being actively investigated for conditions with complex etiology, including not only genetic, but also environmental factors: heart failure [4, 5], joint inflammatory diseases [6], neurological and neurodegenerative diseases [7-9], malignant tumors [10, 11], and morbid viral infections [12].

\section{Therapeutic goals of the rAAV-mediated gene delivery}

Therapeutic goal of nucleic acid delivery refers to molecular mechanisms of the compensatory effect. For monogenic diseases, a default option is functional replacement of the mutant gene copies with properly operating transcriptional units. As an alternative to gene replacement, the therapy may be aimed at correction of signaling pathways by adding active genes (gene addition), specific shutdown of target genes by transgene expression products at the level of transcription, translation, or protein (gene silencing), as well as delivery of DNA templates for genome editing e.g. CRISPR-based (gene editing) [2].

\section{The choice of administration route depending on target structures}

Local administration of the drug is a proper choice for pathological processes localized in accessible anatomical compartments (eyeball, joint). For pathologies of the central nervous system (CNS), the drug can be injected into a specific area of the brain or cerebrospinal fluid; however, both procedures are highly invasive. The feasibility of minimally invasive systemic administration of viral particles depends on clinical situation.

For local administration of rAAV, the choice of serotype is non-critical. By contrast, when the drug is administered systemically, the success of therapy largely depends on the choice of serotype for the most selective transduction of target organs and tissues. The liver and the muscles are targeted more effectively than other organs.

The liver can be targeted with almost any known human AAV serotype. This is consistent with the fact that the majority of natural AAV strains in humans and primates infect hepatic and splenic tissues. Hepatocytes represent the primary target for a number of monogenic metabolic disorders, including familial hypercholesterolemia $(L D L R)$, ornithine transcarbamylase deficiency (OTC), Crigler-Najjar syndrome (UGT1A1), hemophilia A (F8), hemophilia B (F9), glycogen storage disease type la (G6PC), and mucopolysaccharidosis type I, II, IIIA or VI (respectively, IDUA, IDS, SGSH or ARSB).

The muscles can be targeted with AAV8 and AAV9 serotypes. Nosological scope for primary targeting of muscle tissues includes Duchenne muscular dystrophy (DMD), Pompe disease $(G A A)$, and X-linked myotubular myopathy (MTM1). It is important to note that the transduced muscle tissue can serve as a secreted polypeptide factory for the treatment of non-muscle diseases.

Transduction of CNS neurons and glial cells requires either highly invasive injection techniques or the use of AAV serotypes capable of crossing the blood-brain barrier (AAV9, AAVrh.10). Monogenic CNS disorders, for which the use of rAAV platforms is considered relevant, include spinal muscular atrophy $(S M N 1)$, aromatic L-amino acid decarboxylase deficiency $(D D C)$, Canavan disease (ASPA), GM1 gangliosidosis (GLB1), mucopolysaccharidosis type III (GNS, HGSNAT, NAGLU, $S G S H)$, Rett syndrome (MECP2), and Batten disease (CLN2, CLN6) [2].

\section{The importance of serotype}

Design of rAAV serotypes produced an entire area of applied research. At the systemic level, the serotype must ensure effective drug targeting with minimal immunogenicity (the immune response can be directed towards transgene expression product if it is foreign. At the subcellular level, the serotype must ensure (1) particle integrity during endosomal transport (endosomal escape) and (2) particle resistance to proteasomal degradation in cytosol before transportation to the nucleus, where viral DNA exits the capsid. Serotype design is based on modifying the structure of AAV capsid proteins encoded by cap gene. Contemporary approaches for obtaining capsids with enhanced properties include directed evolution, rational design, and natural discovery.

Directed evolution stands for artificial selection of successful variants after random modification of the template by using polymerase chain reaction of low fidelity (error-prone PCR) or multiple fragment swapping between different variants of the same sequence (capsid shuffling). Rational design means targeted optimization of a serotype using protein engineering methods. Alterations in polypeptide structure are introduced at the level of the coding templates. Site-directed mutagenesis allows single substitutions at antigenically relevant amino acid positions in a polypeptide. For example, substitutions of tyrosine residues exposed at the particle surface can significantly increase the efficacy of endosomal transport after particle internalization and their resistance to proteasomal degradation in the cytosol; a corresponding enhancement of transduction efficiency has been demonstrated in a mouse model [13]. Modification of epitopes in the already assembled capsids can be carried out by chemical methods [14]. Another area of rational capsid design for rAAV is creation of cap chimeric genes. The selectivity of targeting can be enhanced by introducing integrin-binding motifs or immunoglobulin-like ScFv domains with high affinity to surface markers of target cells.

Finally, new relevant AAV serotypes can be discovered by analyzing high-throughput data produced by 'omics' technologies. Competent borrowing from nature should always involve comprehensive examination of the available options. The majority of natural AAV strains are species-specific: some infect humans, other infect mice, etc. The prevalence of AAVspecific antibodies in human populations may reach $80 \%$ [15]. 
If we 'dress' our therapeutic construct in the capsid of one of the human AAV strains, the immune system may quickly attack the drug, the titer will decrease rapidly, and the transduction will be ineffective. On the other hand, if we take a capsid (serotype) very distant from human serotypes (e.g. murine), then, firstly, we risk an excessive immune response with the most severe consequences. Secondly, the affinity of the particles to the receptors at the surface of target cells may not be strong enough, since murine AAV serotypes have been adapted to murine receptors by the evolution, and the transduction will fail as well. The problem has two solutions.

1. When borrowing serotypes from closely related species, the risk of excessive immune response is moderate. At the same time, the patient lacks high-affinity prêt-à-porter antibodies, while receptors at the surface of target cells may recognize such particles satisfactorily thus promoting efficient transduction. This is not just an idea; for example, in the designation of the serotype AAVrh.10, already established in clinical studies, 'rh' is derived from 'rhesus monkeys' (Macaca mulatta).

2. It is also possible to use serotypes once present in the human virome but already dismissed by evolution. Such ancestral serotypes, to which we harbor no antibodies, are found by computational methods of evolutionary genetics in silico.

In the practical aspect, it is important to understand that serotype design is a formidable task, which requires comprehensive functional testing. To generate options is easy enough, but their proper evaluation is methodologically challenging. Today, only about a dozen different rAAV serotypes have been promoted to clinical applications, including trials, with AAV2 being the most favored. The list includes several relatively new serotypes with enhanced targeting properties, most notably AAV8, AAV9, and AAVrh.10 [2].

\section{Design of therapeutic modules}

Design of cargoes for rAAV-mediated gene delivery is tricky. ITR are the only sequences left from the prototype viral genome, with the rest space reserved for a therapeutic module. A minimal cassette comprises a promoter, a coding sequence, and a $3^{\prime}$ noncoding region with polyadenylation and transcription termination signals. The packaging size limit is 4,700 nucleotides, including ITR. Experimental attempts of packaging for constructs larger than 5,200 nucleotides produced particles containing fragments of variable length with truncated (chopped off) $5^{\prime}$ termini. Such defective particles were capable of delivering reporter genes in vitro only at a high multiplicity of infection, which is completely unacceptable for in vivo applications [3]. The principles and pitfalls of the therapeutic module engineering are given in Table.

\section{Manufacturing options}

Production of recombinant viruses harnesses eukaryotic cells as biological factories. The most convenient solutions involve special cell lines genetically modified for the task - the socalled packaging cell lines with certain (but not all) genes required for the production of recombinant viral particles built into their own chromosomes.

The first packaging cell lines for rAAV were HeLa cells stably transfected with (i. e. they are having built-in copies of) rep-cap genes and the rAAV genome per se - a therapeutic module flanked with ITR. Production of rAAV particles in this system is triggered by infection of the cells with adenovirus (AdV). A serious drawback of this system is the presence of adventitious AdV (inactivated by heating the isolates at $56^{\circ} \mathrm{C}$ for $30-60$ minutes, to which rAAV is resistant.) Another disadvantage of this system is nonversatility, as a new line of genetically modified HeLa cells had to be obtained for each new construct-serotype combination [22]. More recent systems for rAAV manufacturing used replicationdeficient herpes simplex virus (HSV) as a helper [23].

The majority of currently established protocols for rAAV manufacturing employ a line of HEK293 cells with two built-in AdV genes, E1a and E1b. Other necessary AdV genes reside in the helper plasmid fed into the system only at the start of the production cycle. The separation of AdV genes into different vehicle molecules is due to safety concerns: co-existence of significant portion of the AdV genetic material in a cell can lead to recombination restoring a replication-competent $\mathrm{AdV}$, contagious and potentially hazardous. Another plasmid, called cis-plasmid, carries the replication template - a therapeutic module flanked by ITR. Yet another vehicle molecule required for the production, called trans-plasmid, contains coding sequences of rep and cap - these are AAV genes, expression of which is indispensable for the replication of rAAV DNA and the packaging of viral particles. All three plasmids involved in the production (helper, cis-, and trans-) are genetically engineered molecules with structures thoroughly verified by sequencing. The plasmids are amplified in E. coli to amounts required for the transfection.

Transfection is a gentle non-viral method of delivering genetic material to eukaryotic cells. In transfection, genetic material enters the cell by means of phagocytosis (in contrast with transduction, which involves the use of viral delivery mechanisms). DNA is incorporated into colloidal particles of some suitable physiologically neutral substance (calcium phosphate, lipofectamine, polyethyleneimine) and these particles are fed to the cells. Most transfection protocols use the same scheme: plasmid DNA is diluted with a small volume of serum-free medium or saline, so is the filler substance; the aliquots are combined, incubated to form phagocytable complexes, and added to the cells. It is important to note that the HEK293 ${ }^{E 1 a b}$ cell line has been adapted for suspension growth in order to enhance the yields [2, 24].

Replication of rAAV in living cells may be accompanied by capturing small fragments of cellular genetic material by the virus. Considering that both HeLa and HEK293 cell lines are derived from humans, the safety of such capturing events is questionable. Contamination of therapeutic constructs with cellular sequences can facilitate their integration into the patient's genome, causing genotoxic effects. To circumvent this problem, it was proposed to use insect Sf9 cells in combination with compatible baculovirus helper sequences; the concept seems to work out [25].

Regardless of a particular protocol used for rAAV production, not only the culture medium (supernatant) but also the cells must be collected at the end of the production cycle, since a significant portion of the particles remain trapped. (In retro- and lentivirus manufacturing, it is usually sufficient to collect the supernatant.) A huge amount of free viral and non-viral DNA in the cell lysates makes a DNAse treatment mandatory. In addition, there is always an admixture of empty and underassembled particles, which must be eliminated by centrifugation in a $\mathrm{CsCl}$ or iodixanol density gradient followed by several rounds of chromatography. Purification of rAAV particles by ultracentrifugation is possible for research applications only and cannot be scaled up for manufacturing purposes [26].

\section{Conclusion}

The global clinical experience with rAAV is actively expanding, and the interest in this research area remains very high. The first rAAV-based drug fully approved for clinical use was Glybera ${ }^{\oplus}$ (a.k.a. Alipogene tiparvovec, uniQure; the Netherlands) 
Table. Design of cargo sequences for rAAV-mediated gene therapy

\begin{tabular}{|c|c|c|c|}
\hline $\begin{array}{l}\text { Basic } \\
\text { requirements }\end{array}$ & Problems & Possible solutions & Examples and comments \\
\hline \multirow{6}{*}{$\begin{array}{l}\text { The } \\
\text { therapeutic } \\
\text { effect should } \\
\text { be maximized }\end{array}$} & \multirow{5}{*}{$\begin{array}{l}\text { Transgene expression level may } \\
\text { be insufficient }\end{array}$} & Use strong promoters & e. g. cytomegalovirus (CMV) promoter \\
\hline & & $\begin{array}{l}\text { Use additional regulatory } \\
\text { elements facilitating transgene } \\
\text { expression }\end{array}$ & $\begin{array}{l}\text { e. g. introns-enhancers, } \\
\text { the woodchuck hepatitis virus posttranscriptional regulatory element } \\
\text { (WPRE) }\end{array}$ \\
\hline & & $\begin{array}{l}\text { Add the Kozak consensus } \\
\text { sequence }\end{array}$ & $\begin{array}{l}\text { CCACCATG or CCACCATGG, where ATG is the translation initiation } \\
\text { codon }\end{array}$ \\
\hline & & $\begin{array}{l}\text { Optimize codon usage and } \\
\text { GC content }\end{array}$ & \\
\hline & & Eliminate inhibitory motives & $\begin{array}{l}\text { including cryptic splice sites and terminators, as well as secondary } \\
\text { structures that undermine stability of the transcript }\end{array}$ \\
\hline & $\begin{array}{l}\text { Supraphysiological expression } \\
\text { levels of transgene in target and } \\
\text { off-target tissues may be toxic }\end{array}$ & & $\begin{array}{l}\text { The effect was described for transgenes of MECP2 (hepatotoxicity) in } \\
\text { a mouse model of Rett syndrome [16] and } \operatorname{HexA} / \operatorname{HexB} \text { (neurotoxicity) } \\
\text { in a primate model of GM2 gangliosidosis [17] }\end{array}$ \\
\hline \multirow[b]{2}{*}{$\begin{array}{l}\text { Transgene } \\
\text { expression } \\
\text { must be } \\
\text { specific }\end{array}$} & \multirow[b]{2}{*}{$\begin{array}{l}\text { Transgene expression in } \\
\text { off-target structures may } \\
\text { significantly enhance the } \\
\text { immune response to the } \\
\text { product }\end{array}$} & Use tissue-specific promoters & \\
\hline & & $\begin{array}{l}\text { Add binding sites for } \\
\text { microRNA species highly } \\
\text { expressed in antigen- } \\
\text { presenting cells to the } 3^{\prime} \\
\text { noncoding region of the } \\
\text { transgene }\end{array}$ & $\begin{array}{c}\text { Professional antigen-presenting cells express microRNA miR-142-3p. } \\
\text { Addition of miR-142-3p binding sites to the construct reduces } \\
\text { transgene expression in macrophages and dendritic cells, thus } \\
\text { suppressing immune response to the product [18] }\end{array}$ \\
\hline \multirow[b]{2}{*}{$\begin{array}{l}\text { Accomodation } \\
\text { of large } \\
\text { transgenes }\end{array}$} & \multirow[b]{2}{*}{$\begin{array}{l}\text { Coding sequences of certain } \\
\text { genes are lengthy }\end{array}$} & $\begin{array}{l}\text { Save space by creating mini- } \\
\text { and microgens encoding } \\
\text { incomplete polypeptides } \\
\text { with (partially) preserved } \\
\text { functionalities }\end{array}$ & $\begin{array}{c}\text { Clinical potential of this approach is being investigated for Duchenne } \\
\text { disease }(D M D), C E P 290 \text { - associated form of Leber congenital } \\
\text { amaurosis, and dysferlinopathy (DYSF) [2] }\end{array}$ \\
\hline & & $\begin{array}{l}\text { Deliver coding sequences in } \\
\text { portions }\end{array}$ & $\begin{array}{l}\text { The engineering strategy is as follows: divide the open reading } \\
\text { frame at a boundary between protein domains and clone the } \\
\text { fragments into two different vectors for packaging into separate viral } \\
\text { particles, while complementing each construct with recombinogenic } \\
\text { sequences flanked by splice sites for the excision from pre-mRNA. } \\
\text { Alternatively, use post-translational reunification of the protein by } \\
\text { the intein-mediated protein trans-splicing; this route is feasible for } \\
\text { some clinically significant polypeptides (dystrophin, Cas9). Given the } \\
\text { low efficiency of polypeptide integrity reconstitution in experimental } \\
\text { systems, discussion of clinical applications for such approaches } \\
\text { would be premature. Since the success depends on probability of } \\
\text { simultaneous infection of the same target cell with two different } \\
\text { particle types, it may require an increase in the viral load compared } \\
\text { with the standards [2,19] }\end{array}$ \\
\hline $\begin{array}{l}\text { Enhancement } \\
\text { of the } \\
\text { transgene } \\
\text { presence in } \\
\text { target cells }\end{array}$ & $\begin{array}{l}\text { The transgene exists in the form } \\
\text { of non-replicated concatemeric } \\
\text { molecules (episomes) inevitably } \\
\text { diluted in mitotically active cell } \\
\text { populations }\end{array}$ & $\begin{array}{l}\text { Stimulate integration with due } \\
\text { regard to genotoxicity risks }\end{array}$ & $\begin{array}{l}\text { Recombinant AAV-based platforms are the method of choice for } \\
\text { in vivo gene delivery largely because of their safety compared to } \\
\text { retro- and lentiviruses, which become incorporated into the host cell } \\
\text { genome upon the transduction. Extremely rare events of spontaneous } \\
\text { partial integration of rAAV material into human genome are clinically } \\
\text { irrelevant [20]. Site-specific integration of rAAV transgenes can } \\
\text { be achieved by genome editing; however, such interventions are } \\
\text { associated with increased risks of genotoxicity. Undesirable side } \\
\text { effects on chromosomal environment in the case of transgene } \\
\text { integration can be reduced by adding insulator elements [21] }\end{array}$ \\
\hline
\end{tabular}

designed to treat the autosomal-recessive lipoprotein lipase $(\mathrm{LPL})$ deficiency. The enzyme, produced predominantly by adipose and muscle tissues which release it into the blood, is functioning at the inner surface of endothelial lining of the capillaries in extrahepatic tissues. Patients with LPL deficiency experience severe impairment of triglyceride metabolism. The active ingredient of Glybera $^{\circledR}$ is constituted by viral particles with AAV1 serotype, containing a copy of the LPL gene with expression-enhancing elements. Glybera ${ }^{\circledR}$ is administered intramuscularly by multiple injections once in every 10 years. The drug was approved for clinical use in Europe in 2012, but withdrawn from the European Community Register of Orphan Medicinal Products in 2017 due to commercial failure; as of 2018, the treatment was received by 31 patients $[27,28]$.

Another rAAV-based drug, Luxturna ${ }^{\circledR}$ (a.k.a. Voretigene neparvovec, Spark Therapeutics; USA), is known as the first rAAV-based gene therapy approved by the U.S. Food and Drug Administration agency (FDA) in 2017. Luxturna ${ }^{\circledR}$ is used to treat the RPE65-dependent congenital Leber amaurosis, a severe autosomal recessive oculopathy that manifests from birth. The active ingredient of Luxturna ${ }^{\circledast}$ is constituted by viral particles with AAV2 serotype, containing a copy of the RPE65 gene with expressionenhancing elements. The drug is administered by subretinal injection [29].

In 2019, another rAAV-based drug, Zolgensma ${ }^{\circledR}$, for the treatment of autosomal-recessive spinal muscular atrophy, received FDA approval [30]. The query "adeno-associated virus" currently yields a list of 159 studies at ClinicalTrials.gov [31]. The clinical trials are in progress, and since there are still more questions than answers in this area, we can expect them to gain momentum. 
1. Chen W, Yao S, Wan J, Tian Y, Huang L, Wang S, et al. BBBcrossing adeno-associated virus vector: An excellent gene delivery tool for CNS disease treatment. J Control Release. 2021 333: 129-38. DOI: 10.1016/j.jconrel.2021.03.029. PubMed PMID: 33775685.

2. Wang D, Tai PWL, Gao G. Adeno-associated virus vector as a platform for gene therapy delivery. Nat Rev Drug Discov. 2019; 18 (5): 358-78. DOI: 10.1038/s41573-019-0012-9. PubMed PMID: 30710128

3. Wu Z, Yang H, Colosi P. Effect of genome size on AAV vector packaging. Mol Ther. 2010; 18 (1): 80-6. DOI: 10.1038/ mt.2009.255. Epub 2009 Nov 10. PubMed PMID: 19904234.

4. Bass-Stringer S, Bernardo BC, May CN, Thomas CJ, Weeks KL, McMullen JR. Adeno-Associated Virus Gene Therapy: Translational Progress and Future Prospects in the Treatment of Heart Failure. Heart Lung Circ. 2018; 27 (11): 1285-300. DOI: 10.1016/j.hlc.2018.03.005. PubMed PMID: 29703647.

5. Greenberg B, Butler J, Felker GM, Ponikowski P, Voors AA, Desai AS, Barnard D, Bouchard A, Jaski B, Lyon AR, Pogoda JM, Rudy JJ, Zsebo KM. Calcium upregulation by percutaneous administration of gene therapy in patients with cardiac disease (CUPID 2): a randomised, multinational, double-blind, placebocontrolled, phase 2b trial. Lancet. 2016; 387 (10024): 1178-86. DOI: 10.1016/S0140-6736(16)00082-9. PubMed PMID: 26803443.

6. Evans $\mathrm{CH}$, Ghivizzani SC, Robbins PD. Gene Delivery to Joints by Intra-Articular Injection. Hum Gene Ther. 2018; 29 (1): 2-14. DOI: 10.1089/hum.2017.181. PubMed PMID: 29160173.

7. Huang L, Wan J, Wu Y, Tian Y, Yao Y, Yao S, et al. Challenges in adeno-associated virus-based treatment of central nervous system diseases through systemic injection. Life Sci. 2021; 270: 119142. DOI: 10.1016/j.Ifs.2021.119142. PubMed PMID: 33524419

8. Mijanović O, Branković A, Borovjagin A, Butnaru DV, Bezrukov EA, Sukhanov RB, Shpichka A, Timashev P, Ulasov I. Battling Neurodegenerative Diseases with Adeno-Associated VirusBased Approaches. Viruses. 2020; 12 (4): 460. DOI: 10.3390/ v12040460. PubMed PMID: 32325732.

9. Privolizzi R, Chu WS, Tijani M, Ng J. Viral gene therapy for paediatric neurological diseases: progress to clinical reality. Dev Med Child Neurol. 2021; 63 (9): 1019-29. DOI: 10.1111/ dmcn.14885. PubMed PMID: 33834479.

10. Nawaz W, Huang B, Xu S, Li Y, Zhu L, Yiqiao H, et al. AAVmediated in vivo CAR gene therapy for targeting human T-cell leukemia. Blood Cancer J. 2021; 11 (6): 119. DOI: 10.1038/ s41408-021-00508-1. PubMed PMID: 34162832.

11. Bower JJ, Song L, Bastola P, Hirsch ML. Harnessing the Natural Biology of Adeno-Associated Virus to Enhance the Efficacy of Cancer Gene Therapy. Viruses. 2021; 13 (7): 1205. DOI: 10.3390/ v13071205. PubMed PMID: 34201599.

12. Colón-Thillet $R$, Jerome KR, Stone D. Optimization of AAV vectors to target persistent viral reservoirs. Virol J. 2021; 18 (1): 85. DOl: 10.1186/s12985-021-01555-7. PubMed PMID: 33892762.

13. Zhong L, Li B, Mah CS, Govindasamy L, Agbandje-McKenna M, Cooper $M$, et al. Next generation of adeno-associated virus 2 vectors: point mutations in tyrosines lead to high-efficiency transduction at lower doses. Proc Natl Acad Sci U S A. 2008; 105 (22): 7827-32. DOI: 10.1073/pnas.0802866105. PubMed PMID: 18511559

14. Kelemen RE, Mukherjee R, Cao X, Erickson SB, Zheng Y, Chatterjee A. A Precise Chemical Strategy To Alter the Receptor Specificity of the Adeno-Associated Virus. Angew Chem Int Ed Engl. 2016; 55 (36): 10645-9. DOI: 10.1002/anie.201604067. PubMed PMID: 27483453.

15. Calcedo R, Morizono H, Wang L, McCarter R, He J, Jones D, et al. Adeno-associated virus antibody profiles in newborns, children, and adolescents. Clin Vaccine Immunol. 2011; 18 (9): 1586-8. DOI: 10.1128/CVI.05107-11. PubMed PMID: 21775517.

16. Gadalla KKE, Vudhironarit T, Hector RD, Sinnett S, Bahey NG, Bailey MES, et al. Development of a Novel AAV Gene Therapy Cassette with Improved Safety Features and Efficacy in a Mouse Model of Rett Syndrome. Mol Ther Methods Clin Dev. 2017; 5: 180-90. DOI: 10.1016/j.omtm.2017.04.007. PubMed PMID: 28497075.

17. Golebiowski D, van der Bom IMJ, Kwon CS, Miller AD, Petrosky K, Bradbury AM, et al. Direct Intracranial Injection of AAVrh8 Encoding Monkey $\beta$-N-Acetylhexosaminidase Causes Neurotoxicity in the Primate Brain. Hum Gene Ther. 2017; 28 (6): 510-22. DOI: 10.1089/hum.2016.109. PubMed PMID: 28132521.

18. Majowicz A, Maczuga $P$, Kwikkers $K L$, van der Marel S, van Logtenstein R, Petry H, et al. Mir-142-3p target sequences reduce transgene-directed immunogenicity following intramuscular adeno-associated virus 1 vector-mediated gene delivery. J Gene Med. 2013; 15 (6-7): 219-32. DOI: 10.1002/jgm.2712. PubMed PMID: 23658149

19. Chamberlain K, Riyad JM, Weber T. Expressing Transgenes That Exceed the Packaging Capacity of Adeno-Associated Virus Capsids. Hum Gene Ther Methods. 2016; 27 (1): 1-12. DOI: 10.1089/hgtb.2015.140. PubMed PMID: 26757051.

20. Kaeppel C, Beattie SG, Fronza R, van Logtenstein R, Salmon F, Schmidt $S$, et al. A largely random AAV integration profile after LPLD gene therapy. Nat Med. 2013; 19 (7): 889-91. DOl: 10.1038/nm.3230. PubMed PMID: 23770691.

21. Liu M, Maurano MT, Wang H, Qi H, Song CZ, Navas PA, et al. Genomic discovery of potent chromatin insulators for human gene therapy. Nat Biotechnol. 2015; 33 (2): 198-203. DOI: 10.1038/ nbt.3062. PubMed PMID: 25580597.

22. Clark KR, Voulgaropoulou F, Fraley DM, Johnson PR. Cell lines for the production of recombinant adeno-associated virus. Hum Gene Ther. 1995; 6 (10): 1329-41. DOl: 10.1089/hum.1995.6.101329. PubMed PMID: 8590738.

23. Clément N, Knop DR, Byrne BJ. Large-scale adeno-associated viral vector production using a herpesvirus-based system enables manufacturing for clinical studies. Hum Gene Ther. 2009; 20 (8): 796-806. DOI: 10.1089/hum.2009.094. PubMed PMID: 19569968.

24. Grieger JC, Soltys SM, Samulski RJ. Production of Recombinant Adeno-associated Virus Vectors Using Suspension HEK293 Cells and Continuous Harvest of Vector From the Culture Media for GMP FIX and FLT1 Clinical Vector. Mol Ther. 2016; 24 (2): 287-97. DOI: 10.1038/mt.2015.187. PubMed PMID: 26437810.

25. Kondratov O, Marsic D, Crosson SM, Mendez-Gomez HR, Moskalenko O, Mietzsch M, et al. Direct Head-to-Head Evaluation of Recombinant Adeno-associated Viral Vectors Manufactured in Human versus Insect Cells. Mol Ther. 2017; 25 (12): 2661-75. DOI: 10.1016/j.ymthe.2017.08.003. PubMed PMID: 28890324.

26. Nass SA, Mattingly MA, Woodcock DA, Burnham BL, Ardinger JA, Osmond SE, et al. Universal Method for the Purification of Recombinant AAV Vectors of Differing Serotypes. Mol Ther Methods Clin Dev. 2017; 9: 33-46. DOI: 10.1016/j. omtm.2017.12.004. PubMed PMID: 29349097.

27. Available from: https://en.wikipedia.org/wiki/Alipogene tiparvovec.

28. Balasubramanian S, Aggarwal P, Sharma S. Lipoprotein Lipase Deficiency. In: StatPearls Treasure Island (FL): StatPearls Publishing; 2021. PubMed PMID: 32809630.

29. Available from: https://en.wikipedia.org/wiki/Voretigene_neparvovec.

30. Available from: https://www.askbio.com/newly-approved-spinalmuscular-atrophy-gene-therapy-zolgensma-validates-askbiogene-therapy-platform/.

31. Available from: https://clinicaltrials.gov/ct2/results?cond=\&term=adenoassociated+virus\&cntry $=\&$ state $=\&$ city $=\&$ dist $=$ retrieved on 202110-26. 
1. Chen W, Yao S, Wan J, Tian Y, Huang L, Wang S, et al. BBBcrossing adeno-associated virus vector: An excellent gene delivery tool for CNS disease treatment. J Control Release. 2021; 333: 129-38. DOI: 10.1016/j.jconrel.2021.03.029. PubMed PMID: 33775685.

2. Wang D, Tai PWL, Gao G. Adeno-associated virus vector as a platform for gene therapy delivery. Nat Rev Drug Discov. 2019; 18 (5): 358-78. DOI: 10.1038/s41573-019-0012-9. PubMed PMID: 30710128.

3. Wu Z, Yang H, Colosi P. Effect of genome size on AAV vector packaging. Mol Ther. 2010; 18 (1): 80-6. DOI: 10.1038/ mt.2009.255. Epub 2009 Nov 10. PubMed PMID: 19904234

4. Bass-Stringer S, Bernardo BC, May CN, Thomas CJ, Weeks KL, McMullen JR. Adeno-Associated Virus Gene Therapy: Translational Progress and Future Prospects in the Treatment of Heart Failure. Heart Lung Circ. 2018; 27 (11): 1285-300. DOI: 10.1016/j.hlc.2018.03.005. PubMed PMID: 29703647.

5. Greenberg B, Butler J, Felker GM, Ponikowski P, Voors AA, Desai AS, Barnard D, Bouchard A, Jaski B, Lyon AR, Pogoda JM, Rudy JJ, Zsebo KM. Calcium upregulation by percutaneous administration of gene therapy in patients with cardiac disease (CUPID 2): a randomised, multinational, double-blind, placebocontrolled, phase 2b trial. Lancet. 2016; 387 (10024): 1178-86. DOI: 10.1016/S0140-6736(16)00082-9. PubMed PMID: 26803443.

6. Evans $\mathrm{CH}$, Ghivizzani SC, Robbins PD. Gene Delivery to Joints by Intra-Articular Injection. Hum Gene Ther. 2018; 29 (1): 2-14. DOI: 10.1089/hum.2017.181. PubMed PMID: 29160173.

7. Huang L, Wan J, Wu Y, Tian Y, Yao Y, Yao S, et al. Challenges in adeno-associated virus-based treatment of central nervous system diseases through systemic injection. Life Sci. 2021; 270: 119142. DOI: 10.1016/j.lfs.2021.119142. PubMed PMID: 33524419.

8. Mijanović O, Branković A, Borovjagin A, Butnaru DV, Bezrukov EA, Sukhanov RB, Shpichka A, Timashev P, Ulasov I. Battling Neurodegenerative Diseases with Adeno-Associated VirusBased Approaches. Viruses. 2020; 12 (4): 460. DOl: 10.3390/ v12040460. PubMed PMID: 32325732.

9. Privolizzi R, Chu WS, Tijani M, Ng J. Viral gene therapy for paediatric neurological diseases: progress to clinical reality. Dev Med Child Neurol. 2021; 63 (9): 1019-29. DOI: 10.1111/ dmcn.14885. PubMed PMID: 33834479.

10. Nawaz W, Huang B, Xu S, Li Y, Zhu L, Yiqiao H, et al. AAVmediated in vivo CAR gene therapy for targeting human T-cell leukemia. Blood Cancer J. 2021; 11 (6): 119. DOI: 10.1038/ s41408-021-00508-1. PubMed PMID: 34162832.

11. Bower JJ, Song L, Bastola P, Hirsch ML. Harnessing the Natural Biology of Adeno-Associated Virus to Enhance the Efficacy of Cancer Gene Therapy. Viruses. 2021; 13 (7): 1205. DOI: 10.3390/ v13071205. PubMed PMID: 34201599.

12. Colón-Thillet R, Jerome KR, Stone D. Optimization of AAV vectors to target persistent viral reservoirs. Virol J. 2021; 18 (1): 85. DOI: 10.1186/s12985-021-01555-7. PubMed PMID: 33892762.

13. Zhong L, Li B, Mah CS, Govindasamy L, Agbandje-McKenna M, Cooper $M$, et al. Next generation of adeno-associated virus 2 vectors: point mutations in tyrosines lead to high-efficiency transduction at lower doses. Proc Natl Acad Sci U S A. 2008; 105 (22): 7827-32. DOI: 10.1073/pnas.0802866105. PubMed PMID: 18511559.

14. Kelemen RE, Mukherjee R, Cao X, Erickson SB, Zheng Y, Chatterjee A. A Precise Chemical Strategy To Alter the Receptor Specificity of the Adeno-Associated Virus. Angew Chem Int Ed Engl. 2016; 55 (36): 10645-9. DOI: 10.1002/anie.201604067. PubMed PMID: 27483453.

15. Calcedo R, Morizono H, Wang L, McCarter R, He J, Jones D, et al. Adeno-associated virus antibody profiles in newborns, children, and adolescents. Clin Vaccine Immunol. 2011; 18 (9): 1586-8. DOI: 10.1128/CVI.05107-11. PubMed PMID: 21775517.

16. Gadalla KKE, Vudhironarit T, Hector RD, Sinnett S, Bahey NG, Bailey MES, et al. Development of a Novel AAV Gene Therapy Cassette with Improved Safety Features and Efficacy in a Mouse Model of Rett Syndrome. Mol Ther Methods Clin Dev. 2017; 5: 180-90. DOI: 10.1016/j.omtm.2017.04.007. PubMed PMID: 28497075.

17. Golebiowski D, van der Bom IMJ, Kwon CS, Miller AD, Petrosky K, Bradbury AM, et al. Direct Intracranial Injection of AAVrh8 Encoding Monkey $\beta$-N-Acetylhexosaminidase Causes Neurotoxicity in the Primate Brain. Hum Gene Ther. 2017; 28 (6): 510-22. DOI: 10.1089/hum.2016.109. PubMed PMID: 28132521.

18. Majowicz A, Maczuga $P$, Kwikkers $K L$, van der Marel $S$, van Logtenstein R, Petry H, et al. Mir-142-3p target sequences reduce transgene-directed immunogenicity following intramuscular adeno-associated virus 1 vector-mediated gene delivery. J Gene Med. 2013; 15 (6-7): 219-32. DOI: 10.1002/jgm.2712. PubMed PMID: 23658149.

19. Chamberlain K, Riyad JM, Weber T. Expressing Transgenes That Exceed the Packaging Capacity of Adeno-Associated Virus Capsids. Hum Gene Ther Methods. 2016; 27 (1): 1-12. DOI: 10.1089/hgtb.2015.140. PubMed PMID: 26757051

20. Kaeppel C, Beattie SG, Fronza R, van Logtenstein R, Salmon F, Schmidt $S$, et al. A largely random AAV integration profile after LPLD gene therapy. Nat Med. 2013; 19 (7): 889-91. DOI: 10.1038/nm.3230. PubMed PMID: 23770691.

21. Liu M, Maurano MT, Wang H, Qi H, Song CZ, Navas PA, et al. Genomic discovery of potent chromatin insulators for human gene therapy. Nat Biotechnol. 2015; 33 (2): 198-203. DOI: 10.1038/ nbt.3062. PubMed PMID: 25580597.

22. Clark KR, Voulgaropoulou F, Fraley DM, Johnson PR. Cell lines for the production of recombinant adeno-associated virus. Hum Gene Ther. 1995; 6 (10): 1329-41. DOI: 10.1089/hum.1995.6.101329. PubMed PMID: 8590738.

23. Clément N, Knop DR, Byrne BJ. Large-scale adeno-associated viral vector production using a herpesvirus-based system enables manufacturing for clinical studies. Hum Gene Ther. 2009; 20 (8): 796-806. DOI: 10.1089/hum.2009.094. PubMed PMID: 19569968.

24. Grieger JC, Soltys SM, Samulski RJ. Production of Recombinant Adeno-associated Virus Vectors Using Suspension HEK293 Cells and Continuous Harvest of Vector From the Culture Media for GMP FIX and FLT1 Clinical Vector. Mol Ther. 2016; 24 (2): 287-97. DOI: 10.1038/mt.2015.187. PubMed PMID: 26437810.

25. Kondratov O, Marsic D, Crosson SM, Mendez-Gomez HR, Moskalenko O, Mietzsch M, et al. Direct Head-to-Head Evaluation of Recombinant Adeno-associated Viral Vectors Manufactured in Human versus Insect Cells. Mol Ther. 2017; 25 (12): 2661-75. DOI: 10.1016/j.ymthe.2017.08.003. PubMed PMID: 28890324.

26. Nass SA, Mattingly MA, Woodcock DA, Burnham BL, Ardinger $\mathrm{JA}$, Osmond SE, et al. Universal Method for the Purification of Recombinant AAV Vectors of Differing Serotypes. Mol Ther Methods Clin Dev. 2017; 9: 33-46. DOI: 10.1016/j. omtm.2017.12.004. PubMed PMID: 29349097.

27. Available from: https://en.wikipedia.org/wiki/Alipogene_tiparvovec.

28. Balasubramanian S, Aggarwal P, Sharma S. Lipoprotein Lipase Deficiency. In: StatPearls Treasure Island (FL): StatPearls Publishing; 2021. PubMed PMID: 32809630.

29. Available from: https://en. wikipedia.org/wiki/Noretigene neparvovec.

30. Available from: https://www.askbio.com/newly-approved-spinalmuscular-atrophy-gene-therapy-zolgensma-validates-askbiogene-therapy-platform/.

31. Available from: $h$ ttps://clinicaltrials.gov/ct2/results?cond=\&term=adenoassociated + virus $\&$ cntry $=\&$ state $=\& c i t y=\& d i s t=$ retrieved on 2021 $10-26$. 